\title{
KELIMPAHAN BAKTERI Vibrio sp. PADA AIR PEMBESARAN UDANG VANNAMEI (Litopenaeus vannamei) SEBAGAI DETEKSI DINI SERANGAN PENYAKIT VIBRIOSIS
}

\section{THE ABUNDANCE OF Vibrio sp. BACTERIA ON ENLARGEMENT WATER OF WHITELEG SHRIMP (Litopenaeus vannamei) AS THE EARLY DETECTION OF VIBRIOSIS}

\author{
Adnan Kharisma dan Abdul Manan \\ Fakultas Perikanan dan Kelautan Universitas Airlangga \\ Kampus C Mulyorejo - Surabaya, 60115 Telp. 031-5911451
}

\begin{abstract}
The abundance of bacteria is an activity that aims to determine the distribution and the abundance of bacteria in a water area, so an effort to control and prevent against these bacteria can be made to avoid it's wide spread. The function of this monitoring activities is for an early detection of animal health conditions that is the white leg shrimp due to bacterial attack. Given the importance of health level in the cultivation of white leg shrimp, then the monitoring activity in bacterial abundance should be done because the number of bacteria found in aquatic environments shouldn't exceed the minimum threshold number of bacteria that is $10^{4} \mathrm{CFU} / \mathrm{ml}$.

The purpose of this study case is to know the abundance of Vibrio sp. on white leg shrimp water augmentation. Because the Vibrio sp. bacteria is known as the opportunistic pathogen of white leg shrimp, which can cause disease if the environmental conditions are bad. Working methods used is descriptive method of data collection techniques include primary and secondary data.

The stage of the monitoring activity include: (1) Preparation phase which includes the preparation of equipment and materials and sterilization equipment and media. (2) Phase of making trisalt solvent and bacterial culture media. (3) Phase of retrieval and delivery the water samples. (4) Phase planting the water samples. (5) Phase counting the bacteria. (6) Interpretation the results of the calculation.

Based on the results of monitoring the abundance of bacteria in white leg shrimp water augmentation activity, the conclusion is the abundance of Vibrio sp. on white leg shrimp water augmentation has exceeds the minimum threshold number of bacteria that is $10^{4} \mathrm{CFU} / \mathrm{ml}$, so the white leg shrimp culture is susceptible againts these Vibriosis disease.
\end{abstract}

Keywords : Vibrio sp., whiteleg shrimp, early detection

\section{Pendahuluan}

Sektor perikanan di Indonesia sangat potensial dan mempunyai prospek yang besar dalam peningakatan devisa negara, salah satunya adalah usaha budidaya udang vannamei (Litopenaeus vannamei). Permintaan udang vannamei di pasar luar negeri yang sangat tinggi dapat meningkatkan devisa negara (Agustatik dkk., 2003). Usaha budidaya udang vannamei baru diperkenalkan pada tahun 2000 di Indonesia, sejak turunnya produksi udang windu. Industri budidaya udang windu di Indonesia telah berkembang sejak tahun 1980 dan mencapai prestasi yang membanggakan pada tahun 1994 sebagai negara yang memproduksi dan mengeksport udang windu terbesar kedua di dunia. Udang windu saat ini tidak berkembang lagi karena terserang berbagai macam penyakit udang yang ganas seperti penyakit white spot atau virus bintik putih (Chamberlain, 1991).
Permintaan udang vannamei sangat besar baik pasar lokal maupun internasional, karena memiliki keunggulan nilai gizi yang sangat tinggi serta memiliki nilai ekonomis yang cukup tinggi menyebabkan pesatnya budidaya udang vannamei (Mahbubillah, 2011). Hal tersebut menyebabkan kemungkinan serangan penyakit pada udang vannamei sangat besar. Penyakit yang ditimbulkan oleh bakteri, virus, dan jamur dapat terjadi apabila terjadi ketidakseimbangan antara Host, Pathogen Agent, dan Environment. (Zonneveld et al., 1991). Pada budidaya udang, penyakit yang mudah timbul umumnya disebabkan oleh bakteri Vibrio sp. (Ruangpan dan Kitao, 1991). Jenis bakteri ini mampu berkembang dengan cepat jika bahan organik dalam air tambak banyak. Menurut Singh (1986) dan Hameed (1993), apabila populasi Vibrio sp. lebih banyak dibanding dengan populasi bakteri yang lain dapat menyebabkan penurunan tingkat 
kelulushidupan udang pada masa pembenihan dan pembesarannya.

Chanratchakool et al (1994) dan Lightner et al (1996) menyatakan bahwa fluktuasi $\mathrm{pH}$, tingkat oksigen, temperatur, salinitas, kadar amonia, dan sulfat, serta bahanbahan organik yang lain dapat sebagai penyebab stress pada udang dan memicu terjadinya penyakit. Namun, peningkatan jumlah bakteri Vibrio sp. tetap menjadi penyebab utama timbulnya penyakit pada air pembesaran udang di kolam. Penerapan manajemen lingkungan merupakan salah satu langkah efektif yang dapat ditempuh untuk mencegah penularan dan penyebaran penyakit di tambak budidaya ikan maupun udang, sebab tingkat kesehatan ikan dan udang merupakan faktor yang sangat menentukan dalam usaha budidaya (Rosenberry, 1997). Menurut Taslihan dkk (2004), untuk menjaga agar produksi ikan dan udang tetap melimpah dapat dilakukan langkahlangkah sebagai berikut: pengawasan kualitas air, pemberian takaran pakan, dan pemberian dosis probiotik atau antibiotik dalam air kolam dengan tepat (Moriarty, 1999).

Mengingat pentingnya tingkat kesehatan udang dalam usaha budidaya, maka deteksi dini tentang kondisi kesehatan udang vannamei dan kondisi lingkungan perairan sangat diperlukan. Atas dasar pemikiran tersebut, maka dilakukan studi kasus tentang kelimpahan bakteri Vibrio sp. pada air pembesaran udang vannamei sebagai deteksi dini penyakit Vibriosis. Deteksi dini bakteri Vibrio sp. pada air pembesaran udang vannamei dapat juga digunakan sebagai upaya dalam pengawasan kualitas air tambak.

Tujuan dari studi kasus ini adalah untuk mengetahui kelimpahan bakteri Vibrio sp. pada air pembesaran udang vannamei sebagai deteksi dini penyakit Vibriosis.

\section{Metodologi}

Metode yang digunakan adalah metode deskriptif, yaitu metode yang menggambarkan kejadian atau keadaan pada suatu kondisi tertentu. Menurut Suryabrata (1993), metode deskriptif adalah suatu metode yang bertujuan untuk memberikan gambaran umum, sistematis, faktual dan valid mengenai data-data yang berupa fakta-fakta dan sifat populasi tertentu dari suatu kegiatan. Studi dilaksanakan di Balai Besar Pengembangan Budidaya Air Payau (BBPBAP) Jepara, Jawa Tengah pada tanggal 24 Januari 2011 sampai 24 Februari 2011.

Tahapan dalam kegiatan monitoring kelimpahan bakteri menurut Taslihan dkk (2004) adalah: (1) Tahap Persiapan, meliputi persiapan alat dan bahan dan Sterilisasi alat dan media, (2) Tahap pembuatan larutan Trisalt dan media kultur bakteri, (3) Tahap pengambilan dan pengiriman sample air, (4) Tahap penanaman sampel air, (5) Tahap penghitungan bakteri, dan (6) Interpretasi hasil penghitungan.

Tahap Persiapan

Persiapan Alat dan Bahan

Alat yang digunakan antara lain: Tabung reaksi bertutup, sumbat tabung (kapas), rak tabung, cawan petri, pippeting aid, pipet volume, pembakar spirtus / bunsen, vorteks, erlenmeyer, magnetic stirer, hot plate, ose, spatula, timbangan elektrik, gunting, kertas label, aluminium foil, inkubator, oven, autoklaf. Bahan yang digunakan antara lain: Sample air, nutrient agar, agar TCBS, larutan 3 garam (Trisalt), aquadest, alkohol $70 \%$ dan $96 \%$.

Sterilisasi Alat dan Media

Sterilisasi alat dan media yang dilakukan menggunakan:

1. Pembakar Bunsen, untuk mensterilkan peralatan seperti ose, jarum, dan spatula dengan cara membakar ujung peralatan tersebut di atas api bunsen sampai berpijar.

2. Oven, untuk mensterilkan cawan petri dan pipet volume. Penggunaan alat ini dengan memasukkan alat-alat tersebut kedalam oven dan dipanaskan dengan suhu 160$170^{\circ} \mathrm{C}$ selama $1-2$ jam.

3. Autoklave, untuk mensterilkan tabung reaksi bertutup dan erlenmeyer. Penggunaan alat ini dengan memasukkan alat-alat tersebut kedalam autoklave yang ditutup dengan rapat dan nyalakan autoklave dengan temperature $121^{\circ} \mathrm{C}$ dan tekanan antara 15-17,5 psi (pound per square inci) atau $1 \mathrm{~atm}$ selama 1 jam.

Tahap Pembuatan Larutan Trisalt dan Media Kultur Bakteri

Pembuatan larutan Trisalt

Pembuatan larutan Trisalt ini dengan mencampurkan 0,75 gram $\mathrm{KCl}, 6,94$ gram $\mathrm{MgSO}_{4}$ dan 23,4 gram $\mathrm{NaCl}$ kedalam labu Erlenmeyer yang berisi $1000 \mathrm{ml}$ akuades kemudian dilarutkan. Lalu $9 \mathrm{ml}$ larutan Trisalt dimasukkan kedalam tabung reaksi berpenutup dan disterilkan dengan memasukkan kedalam Autoklave.

Media Kultur Bakteri

Media kultur bakteri yang dipergunakan adalah Nutrient Agar (NA) dan Thiosulfat Citrate Bile Salts Sucrose Agar (TCBSA). 
Tahap Pengambilan dan Pengiriman Sampel Air Menurut Frerichs and Millar (1993), untuk mendapatkan sampel yang baik dan representatif diperlukan beberapa persyaratan antara lain: (1) Pemilihan lokasi yang tepat, (2) Penetapan frekuensi pengambilan sampel, (3) Cara pengambilan sampel, dan (4) Perlakuan sampel di lapangan.

Pengambilan sampel air, pertama-tama dengan mencuci botol tempat sampel dengan detergen sampai bersih, lalu botol dibilas ulang dengan aquades bebas ion, bebas amoniak, bebas nitrit, sesuai dengan uji parameter. Setelah itu diletakkan di box tertutup untuk menghindari kontaminasi. Sample air di ambil dari 6 bak terpisah dengan kode bak B4, B5, B7, B8, B9, dan BLT B2, sebanyak 5x selama 5 minggu.

Dalam proses pengambilan sample air, lokasi pengambilan sampel air dilakukan secara random. Air tambak kemudian dimasukkan kedalam tabung sample dengan cara membuka tutup tabung sample dalam keadaan tercelup didalam bak tersebut. Ambil sample air sebanyak $10 \mathrm{ml}$. Pengisian dilakukan sampai penuh dan pastikan tidak ada celah antara sample air dengan tutup botol, agar tidak terjadi kontaminasi dengan udara.

Catat identitas contoh antara lain tanggal, lokasi, dan paraf pengambil sample. Sample air disimpan dalam box penutup botol sampel kemudian ditutup rapat, disegel dan ditutup dengan alumunium foil agar terhindar dari cahaya matahari. Tabung sample kemudian dibawa ke laboratorium mikrobiologi divisi Manajemen Kesehatan Hewan Akuatik (MKHA) Balai Besar Pengembangan Budidaya Air Payau (BBPBAP) Jepara untuk dilakukan analisis kualitas air berdasarkan total bakteri yang ada.

Proses pengambilan dan pengiriman sampel air yang dilakukan sesuai prosedur kelayakan seperti yang diungkapkan oleh Frerichs dan Millar, sehingga sampel air yang didapat dipastikan bebas kontaminasi sehingga layak untuk dianalisis hasilnya.

\footnotetext{
Tahap Penanaman Sampel Air

Cara dalam penanaman sampel air ini yaitu sample air dihomogensikan dengan cara dikocok terlebih dahulu menggunakan vorteks, diambil sebanyak $1 \mathrm{ml}$ dengat pipet ukur dan dimasukkan kedalam larutan trisalt secara aseptik. Menurut Taslihan dkk (2004), untuk pengisolasian total bakteri, sample air diencerkan hingga $100 \mathrm{ml}$ sedangkan untuk pengisolasian bakteri Vibrio sp., sampel air dari diencerkan hingga $10 \mathrm{ml}$. Setelah diencerkan,
}

sebanyak $0,1 \mathrm{ml}$ larutan dimasukkan ke dalam media kultur (media NA untuk pengisolasian total bakteri umum dan media TCBSA untuk pengisolasian bakteri Vibrio sp.). Pengisolasian bakteri dilakukan secara aseptik dengan menerapkan metode sebar dimana setelah larutan dimasukkan ke dalam media, larutan tersebut disebar ratakan di permukaan media menggunakan spatula. Media kemudian diinkubasi pada suhu $37^{\circ} \mathrm{C}$ selama 24 jam dalam inkubator.

\section{Tahap Penghitungan Bakteri}

Menurut Bailey and Scott's (1982), penghitungan bakteri dilakukan dengan menerapkan metode total plate count (TPC). Jumlah bakteri yang muncul dihitung dengan menggunakan alat colony counter yang kemudian dicatat dan dikalikan dengan besaran pengenceran yang telah dilakukan. Jumlah bakteri dinyatakan dalam satuan CFU/ml (colony-forming unit / $\mathrm{ml}$ ).

Data hasil plate count penghitungan bakteri yang diperoleh ditabulasi dengan menggunakan program excel menjadi sebuah grafik. Grafik tersebut kemudian diinterpretasikan hasilnya apakah total plate count bakteri tersebut dapat menyebabkan penyakit Vibriosis pada udang vannamei. Sumbu axis dari grafik yang dibuat merupakan tanggal pengambilan sampel air selama 30 hari mulai tanggal 24 Januari 2011 hingga 24 Februari 2011.

Data diambil sebanyak lima kali selama lima minggu dan diambil pada setiap minggunya. Minggu I tanggal 24 Januari 2011, minggu II tanggal 31 Januari 2011, minggu III tanggal 07 Pebruari 2011, minggu IV tanggal 14 Pebruari 2011, dan minggu $\mathrm{V}$ tanggal 21 Pebruari 2011.

Sumbu ordinat merupakan jumlah total plate count bakteri. Pada penghitungan jumlah bakteri Vibrio sp., sumbu ordinat dalam skala $10^{4}$ sedangkan pada bakteri umum menunjukkan skala $10^{6}$. Data kelimpahan bakteri diperoleh dari 6 bak air pembesaran udang vannamei dengan kode bak B4, B5, B7, B8, B9, dan BLT B2.

\section{Hasil dan Pembahasan}

Menurut Taslihan dkk (2004), ambang batas minimal keberadaan bakteri Vibrio sp. dalam air adalah $10^{4} \mathrm{CFU} / \mathrm{ml}$, sedangkan batas minimal bakteri umum diperairan adalah $10^{6}$ $\mathrm{CFU} / \mathrm{ml}$. Jika ambang batas ini dilampaui maka kematian massal udang budidaya dalam tambak dapat terjadi. Grafik data hasil monitoring kelimpahan bakteri pada air pembesaran udang 


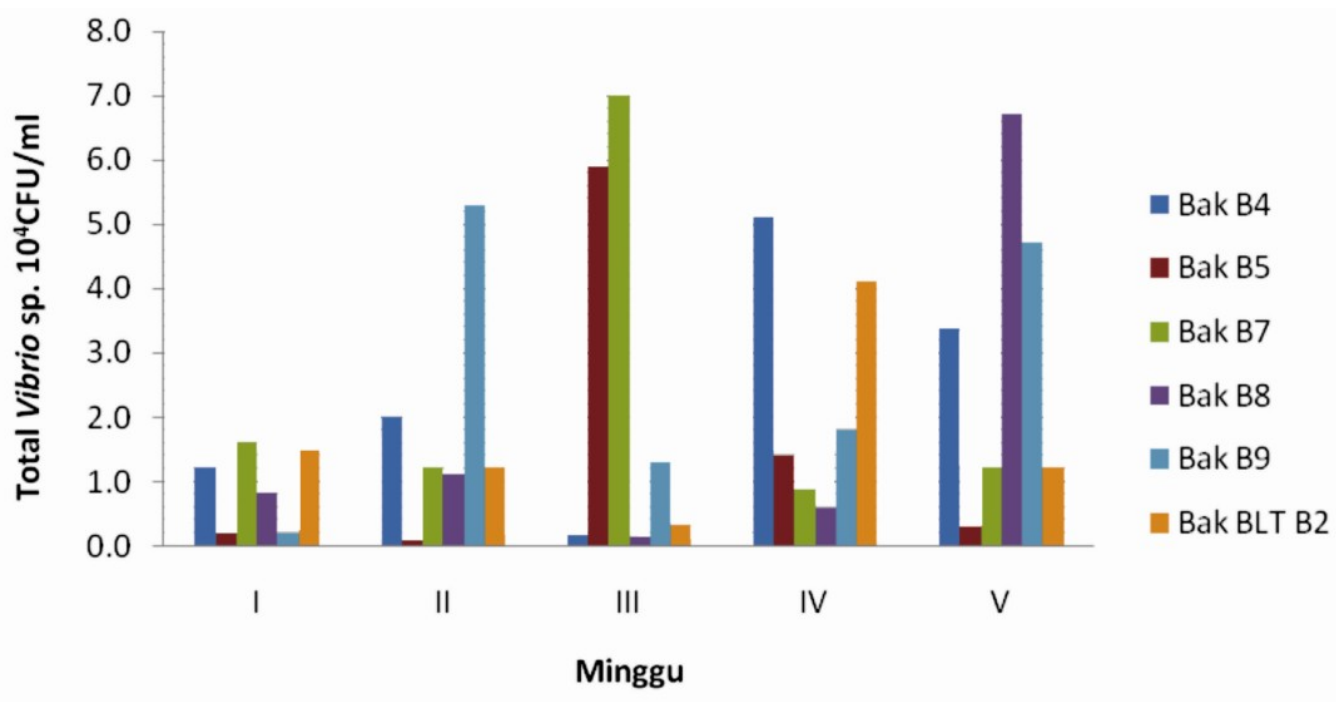

Gambar 1. Pertumbuhan Bakteri Vibrio sp. Selama 5 Minggu

vannamei dapat dilihat pada gambar 1 dan gambar 2 .

Jumlah bakteri Vibrio sp. yang termonitor pada Bak B4 dan BLT B2 terlihat serupa di mana pada minggu ke-1 dan ke-2 meningkat sedikit dan minggu ke-3 turun, namun pada minggu ke-4 meningkat drastis sampai 5,1 x $10^{4}$ bakteri CFU/ml, dan menurun kembali pada minggu ke-5. Meningkatnya jumlah bakteri pada minggu ke-4 disebabkan suhu air yang menurun drastis hingga 27,1 dan $26,8^{\circ} \mathrm{C}$ pada kedua bak tersebut. Pada minggu ke-5 jumlah bakteri berangsur menurun karena suhu bak meningkat menjadi 28,3 dan $27,6^{\circ} \mathrm{C}$.

Jumlah bakteri Vibrio sp. yang termonitor pada Bak B5 dan B7 terlihat serupa di mana pada minggu ke-1 dan ke-2 menurun sedikit dan minggu ke-3 meningkat drastis mencapai $7 \times 10^{4} \mathrm{CFU} / \mathrm{ml}$, namun pada minggu ke-4 menurun drastis sampai $1,1 \times 10^{4} \mathrm{CFU} / \mathrm{ml}$, dan keadaan tetap sampai minggu ke-5. Meningkatnya jumlah bakteri pada minggu ke-3 disebabkan suhu air yang menurun drastis hingga $26,6^{\circ} \mathrm{C}$ pada kedua bak tersebut. Pada minggu ke-4 jumlah bakteri berangsur menurun karena suhu bak meningkat menjadi 28,9 dan $27,5^{\circ} \mathrm{C}$ pada kedua bak.

Jumlah bakteri Vibrio sp. yang termonitor pada Bak B8 dan B9 terlihat serupa di mana pada minggu ke-1 dan ke-2 meningkat sedikit dan minggu ke-3 turun sampai dengan minggu ke-4 sampai $1,8 \times 10^{4} \mathrm{CFU} / \mathrm{ml}$, namun pada minggu ke-5 meningkat drastis hingga 6,7 x $10^{4} \mathrm{CFU} / \mathrm{ml}$ dan perlu dilakukan monitor pada minggu ke-6. Menurunnya jumlah bakteri pada minggu ke-3 dan ke-4 disebabkan suhu air yang naik hingga 28,2 dan $28,1^{\circ} \mathrm{C}$ pada kedua bak tersebut. Peningkatan jumlah bakteri pada minggu ke-5 disebabkan suhu bak yang turun drastis menjadi menjadi $27,1^{\circ} \mathrm{C}$ pada kedua bak.

Hasil monitoring kelimpahan bakteri Vibrio sp. pada air pembesaran udang vannamei menunjukkan bahwa kelimpahan bakteri telah melebihi ambang batas minimal bakteri di perairan yaitu $10^{4}=10000 \mathrm{CFU} / \mathrm{ml}$, sehingga rentan terhadap serangan penyakit Vibriosis. Kelimpahan ini terjadi akibat kondisi lingkungan perairan yang tidak baik disebabkan oleh musim hujan.

Kondisi lingkungan perairan yang tidak baik dibuktikan dengan membandingkan parameter fisika dan kimia kualitas air menurut pustaka yang diperoleh dengan kondisi perairan. Berdasarkan sumber dari Standar Nasional Indonesia (SNI) no 7310 (2009), suhu optimal kualitas air pembesaran udang vannamei adalah $28-32^{\circ} \mathrm{C}$, namun kondisi air pembesaran udang menunjukkan suhu rata-rata $27,7^{\circ} \mathrm{C}$ dengan adanya suhu yang menurun drastis hingga $26,6^{\circ} \mathrm{C}$. Suhu yang terlalu rendah inilah penyebab terjadinya kelimpahan bakteri Vibrio sp. diperairan. $\mathrm{pH}$ optimal adalah antara 7,5 8,5 , sesuai dengan $\mathrm{pH}$ rata-rata air yaitu 7,58 namun ada $\mathrm{pH}$ yang berfluktuasi hingga 7,02. Berdasarkan parameter kimianya, jumlah amoniak maksimal adalah $<0,01 \mathrm{mg} / \mathrm{l}$, nitrit maksimal $<0,01 \mathrm{mg} / 1$, dan nitrat maksimal $<$ $0,5 \mathrm{mg} / \mathrm{l}$. Sedangkan kondisi parameter kimia pada air pembesaran udang vannamei semua data melebihi ambang batas maksimalnya yaitu kadar amoniak 0,1005 mg/l, dengan nitrit mencapai $0,095 \mathrm{mg} / \mathrm{l}$, dan kadar nitrat mencapai $0,948833 \mathrm{mg} / \mathrm{l}$. 


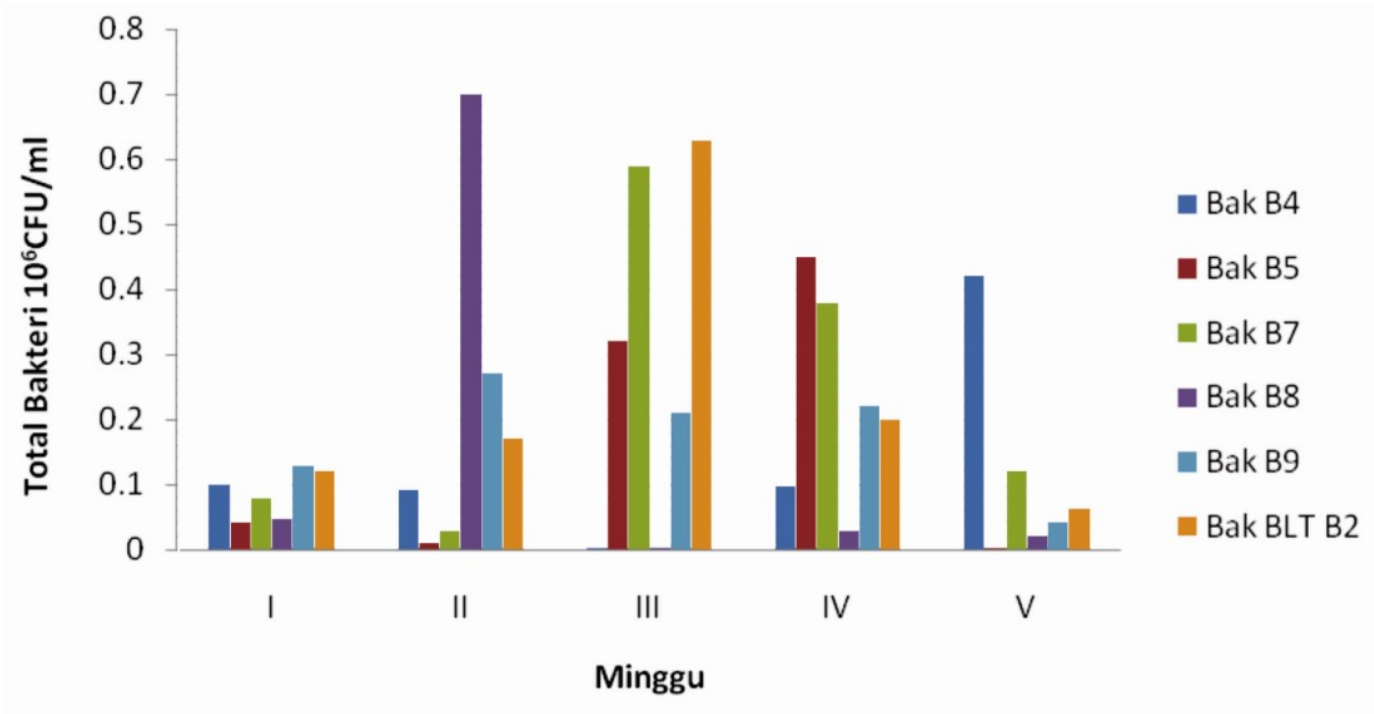

Gambar 2. Pertumbuhan Total Bakteri Selama 5 Minggu

Parameter fisika dan kimia kualitas air yang tidak baik menjadi penyebab melimpahnya jumlah bakteri Vibrio sp. pada air pembesaran udang vannamei. Selain itu, budidaya udang vannamei skala intensif menjadi faktor penyebab mudahnya penyakit Vibriosis menyerang udang vannamei. Hal tersebut dikarenakan udang yang dibudidayakan mengalami stress disebabkan oleh kepadatan populasi udang.

Jumlah bakteri umum yang diperoleh pada air pembesaran udang vannamei menunjukkan bahwa kelimpahan bakteri belum melewati ambang batas minimum bakteri umum diperairan yaitu $10^{6}=1000000 \mathrm{CFU} / \mathrm{ml}$. Artinya jumlah bakteri umum yang ada di perairan masih dalam jumlah sewajarnya, sehingga tidak rentan terhadap serangan suatu penyakit.

\section{Kesimpulan}

Kelimpahan bakteri Vibrio sp. pada air pembesaran udang vannamei telah melebihi ambang batas minimal bakteri di perairan yaitu $10^{4}=10000 \mathrm{CFU} / \mathrm{ml}$, sehingga rentan terhadap serangan penyakit Vibriosis.

Monitoring kelimpahan bakteri Vibrio sp. perlu dilakukan secara berkala untuk mendeteksi secara dini serangan penyakit Vibriosis.

\section{Daftar Pustaka}

Agustatik, S., L. Surya., M.B. Manja., H.W. Arik., S. Akbar., H. Nono., Zakimin., H. Tinggal dan Rusfian. 2003. Manajemen Pembesaran Kerapu Macan Di Karamba Jaring Apung. Loka Budidaya Laut Batam. 45 hal.
Bailey and Scott's. 1982. Diagnostic Microbiology. The CV. Mosby Company S.T. Louis, Toronto, London.

Chamberlain, G.W. 1991. Shrimp Farming in Indonesia, Seedstock Production. World Aquaculture.

Chanratchakool, P., J.F. Turnbull., and C. Limsuwan. 1994. Health Management in Shrimp Ponds. Aquatic Animal Health Research Institute, Thailand.

Hameed, A.S.S. 1993. A Study of the Aerobic Heterotrophic Bacterial Flora of Hatchery-Reared Eggs, Larvae and Postlarvae of Penaeus indicus. Aquaculture, 117:195-204.

Lightner, D.V., T.A. Bell., R.M. Redman., L.L. Mohney., J.M. Natividad., A. Rukyani., and A. Poernomo. 1992. A Review of Some Major Disease of Economic Significance in Penaeid Prawns / Shrimp of the Americans and Indopacific. Proceedings of the First Symposium on Disease in Asian Aquaculture Bali, Indonesia.

Mahbubillah, M.A. Budidaya Udang Vannamei. http://marinebiologi.blogspot.com/

Moriarty, D.J.W. 1999. Disease Control in Shrimp Aquaculture with Probiotic Bacteria. Microbial Interactions in Aquaculture.

Rosenberry, B. 1997. World Shrimp Farming. Annual Report. Shrimp News International, San Diego, California, USA. 164 hal.

Ruangpan, L. and T. Kitao. 1991. Vibrio Bacteria Isolated from Black Tiger 
Shrimp, Penaeus monodon Fabricius. J. Fish Disease. Hal 383-388.

Singh, B.I. 1986. Studies on the Bacteria Associated with Penaeus indicus in a Culture System. Ph.D. Thesis. Cochin University of Science and Technology, Cochin, India, $230 \mathrm{pp}$.

Suryabrata, S. 1993. Metode Penelitian. CV. Rajawali. Jakarta. 115 hal.
Taslihan, A, Ani W, Retna H, S.M. Astuti. 2004. Pengendalian Penyakit Pada Budidaya Ikan Air Payau, Direktorat Jenderal Perikanan Balai Besar Budidaya Air Payau Jepara.

Zonneveld, N., E. A. Huismann., dan J. H. Boon. 1991. Prinsip-prinsip Budidaya Ikan. PT. Gramedia Pustaka Utama. Jakarta. 318 hal. 